\title{
Parental dietary patterns and social determinants of children's dietary patterns
}

\author{
Padrões dietéticos dos pais e determinantes \\ sociais dos padrões alimentares \\ das crianças
}

Rosana SALLES-COSTA ${ }^{1}$

Gabriela dos Santos BARROSO²

Maria CABRAL ${ }^{3}$

Maria Beatriz Trindade de CASTRO $^{1}$

A B S T R A C T

\section{Objective}

To identify dietary patterns in children up to thirty months of age and verify whether they are associated with parental dietary patterns, and socioeconomic and demographic characteristics.

\section{Methods}

This is a cross-sectional study with baseline data from a population-based study composed of 1,085 households from a representative sample of a metropolitan region in Rio de Janeiro, Brazil. The children's food intake was evaluated by two 24-hour recalls, and the dietary patterns were identified by principal component analysis stratified into two groups according to the children's age: 6 to 17 months; and 18 to 30 months. The explanatory variables collected by a structured questionnaire were socioeconomic and demographic characteristics, age at introduction of complementary foods, and parental dietary pattern. A Food Frequency Questionnaire was administered to assess parental dietary pattern, which was determined by principal component analysis. Multivariate linear regression estimated the effect of each explanatory variable on the children's dietary patterns.

\section{Results}

Three dietary patterns were identified in children aged 6-17 months (basic-mixed; mixed-plus; and milk-flours) and two dietary patterns were identified in children aged 18-30 months: basic-mixed and mixed-plus. Multivariate

\footnotetext{
1 Universidade Federal do Rio de Janeiro, Instituto de Nutrição Josué de Castro, Departamento de Nutrição Social e Aplicada. Av. Carlos Chagas Filho, 373, Edifício do Centro de Ciências da Saúde, Bloco J, $2^{\circ}$ andar. Cidade Universitária, 21941-902, Rio de Janeiro, RJ, Brasil. Correspondência para/Correspondence to: R SALLES-COSTA. E-mail: <rosana@nutricao.ufrj.br>.

2 Universidade Federal Fluminense, Hospital Universitário Antônio Pedro, Serviço de Nutrição. Niterói, RJ, Brasil.

3 Universidade do Porto, Instituto de Saúde Pública, Unidade de Pesquisa Epidemiológica. Porto, Portugal. 
linear regression showed that complementary feeding $(\beta=0.108 ; p=0.004)$ was positively associated with the basic-mixed dietary pattern, and family income $(\beta=0.002 ; p \leq 0.01)$, with the mixed-plus dietary pattern. A negative association was found between the traditional parental dietary pattern and children's mixed-plus pattern in children aged $6-17$ months $(\beta=0.152 ; p=0.006)$ and in children aged $18-30$ months $(\beta=0.152 ; p=0.016)$. In children aged up to 18 months, parental education level $(\beta=0.368 ; p \leq 0.01)$ was positively associated with the mixed-plus dietary pattern.

\section{Conclusion}

Family income, parental education level, and parental dietary patterns are associated with children's dietary patterns.

Keywords: Child nutrition. Epidemiology. Socioeconomic factors. Supplementary feeding.

\section{R E S U M O}

\section{Objetivo}

Identificar os padrões dietéticos entre crianças menores de 30 meses de idade e verificar sua associação com os padrões dietéticos dos pais, juntamente com as características socioeconômicas e demográficas.

\section{Métodos}

Estudo transversal de base populacional composto por amostra representativa de 1085 domicilios da região metropolitana do Rio de Janeiro. O consumo alimentar infantil foi estimado através de dois recordatórios de 24 horas, aplicados em dias não consecutivos, e os padrões dietéticos foram identificados por análise de componentes principais, estratificada em dois grupos etários (6-17 meses; 18-30 meses). As informações sociodemográficas (idade dos pais, renda familiar, escolaridade e número de moradores no domicílio) e idade da introdução da alimentação complementar foram coletadas a partir de um questionário estruturado. Aplicou-se o Questionário de Frequência do Consumo Alimentar para avaliar o padrão dietético dos pais, gerado através da análise de componentes principais. Empregou-se a regressão linear multivariada para estimar o efeito de cada variável exploratória em relação ao padrão de consumo das crianças.

\section{Resultados}

Três padrões dietéticos foram identificados entre crianças de 6 a 17 meses de idade (básico-misto; misto; e leite e farinhas infantis) e dois entre crianças de 18 a 30 (básico-misto e misto). Os resultados na análise de regressão multivariada mostraram que a idade de introdução da alimentação complementar $(\beta=0.108 ; p=0.004)$ foi positivamente associado com o padrão básico-misto e a renda familiar $(\beta=0.002 ; p \leq 0.01)$ foi positivamente associada com o padrão misto. Observou-se uma associação negativa entre o padrão alimentar tradicional dos pais e o padrão misto entre as crianças com até 17 meses $(\beta=0.152 ; p=0.006)$ e também entre as crianças com idade entre 18 e 30 meses $(\beta=0.152 ; p=0.016)$. Entre as crianças maiores de 18 meses, obteve-se uma associação positiva da escolaridade dos pais $(\beta=0.368 ; p \leq 0.01)$ e o padrão misto.

\section{Conclusão}

Renda familiar, escolaridade e padrão alimentar dos pais foi associado com os padrões dietéticos das crianças.

Palavras-chave: Nutrição da criança. Epidemiologia. Fatores socioeconômicos. Suplementação alimentar.

\section{INTRODUCTION}

Infant feeding is an important health determinant in the first year of life. Evidence suggests that the food behavior developed in this phase can track into adulthood ${ }^{1}$. Encouraging healthy food habits is a crucial education tool to prevent chronic noncommunicable diseases later on (e.g., type 2 diabetes, obesity, and cardiovascular diseases) as their prevalence has been increasing in the last few decades ${ }^{2}$.

Traditionally, epidemiological studies have tried to establish associations between the intake of nutrients or food groups with health outcomes ${ }^{3}$. However, since people do not consume foods or nutrients separately ${ }^{4}$, and food practices are modulated by social and cultural factors, principal 
component analyses have proven to be more effective in describing food intake in the form of dietary patterns. These can be defined as the set of foods or food groups consumed by a given population, for which principal component analysis is the most widely used method for their identification ${ }^{5}$.

Few studies have evaluated the dietary patterns of children under the age of three ${ }^{6,7}$. In the United Kingdom a population-based cohort study with 7,052 participants aged 6 months and 5,610 aged 15 months found an association between children's dietary patterns and the family's socioeconomic context, as well as the influence exerted by parental dietary patterns, given that parents were responsible for household food availability and quality ${ }^{8}$.

The identification of dietary patterns in nutritional epidemiology opens a new perspective towards more effective health promotion strategies, with nutritionally, socially, and culturally contextualized practices. This study aimed to identify the dietary patterns of children aged up to thirty months, and to verify whether they are associated with parental dietary patterns, and socioeconomic and demographic characteristics.

\section{METHODS}

This is a population-based cross-sectional study with a representative sample of households in Duque de Caxias city, located in the metropolitan area of Rio de Janeiro, Brazil. Details on sample design were previously described by Barroso et al. ${ }^{9}$. Households with at least one child aged six to thirty months were considered eligible for the study. A total of 402 of the 1,085 investigated households were eligible: 366 (91.0\%) completed the children's food intake questionnaires, and 365 (90.8\%) completed the parental food intake questionnaires (mother or father).

The interviews were carried out between May and December 2005. The team of interviewers consisted of fifteen community residents with complete high school and five dietitians, who collected information about the children's and parental food intake. All interviewers were trained by professionals with experience in the administration of structured questionnaires on socioeconomic and demographic characteristics. The group of dietitians received training to collect food intake data. Both the 24-hour recall (24HR) and the Food Frequency Questionnaire (FFQ) were administered to measure the food intake of the children and parents, respectively. The FFQ was previously validated by Sichieri \& Everhart ${ }^{10}$.

The study was approved by the Research Ethics Committee of the Institute of Social Medicine of the Universidade do Estado do Rio de Janeiro (number 02/2004). All participants signed an informed consent form.

Two 24-hour recalls were administered to assess the children's food intake on nonconsecutive days with a maximum interval of two weeks. The dietitians preferably interviewed the parent who spent more time with the child. The 74 items listed in the 24HR were grouped in 18 food groups based on their nutritional characteristics and correlations found by preliminary factor analysis: 1) rice; 2) beans; 3 ) breads (bread loaf or roll); 4) biscuits and cakes; 5) grains and tubers (pasta, flour, polenta or cornmeal porridge, potato, corn, cassava, and yam); 6) non-starchy vegetables (lettuce, cauliflower, chicory, cabbage, chayote, pumpkin, zucchini, string bean, gumbo, carrot, beetroot, cucumber, and tomato); 7) fruits (banana, papaya, apple, melon, pineapple, avocado, mango, lemon, passion fruit, grape, guava, and pear, and fruit juice); 8) cheeses and yogurt (yogurt, cheese, and cottage cheese); 9) milk; 10) baby cereals; 11) sausages and fats (ham, mayonnaise, sausages, potato chips, snacks, and pizza); 12) candies and sweets (ice cream, candies, biscuits, jelly, gelatin, bar chocolate, pies, pudding, and cocoa mixes); 13) oils and margarine (oil, margarine, and butter); 14) meats (steak, chicken, pork, tripe, hamburger, fish, shrimp, and canned sardine or tuna); 15) eggs; 16) sugary drinks (soft 
drinks and drink mixes); 17) sugar; and 18) - coffee. Some foods were kept alone due to high intake frequency (rice, beans, bread), and their incorporation in a distinct food group was considered inappropriate (rice, beans, eggs, milk, sugar, and coffee).

Principal component analysis determined the children's dietary patterns, which were grouped by age: 6 to 17 months $(n=149)$ and 18 to 30 months $(n=216)$. Previous pattern analysis was performed by child's sex (not showed). Since the results were similar, the study evaluated the patterns of both sexes together. The Kaiser-MeyerOlkin test $\geq 0.60$ estimated the applicability and adequacy of the analytical method in relation to the dietary data. Varimax orthogonal rotation was used to improve data interpretation. The number of retained factors was defined by: 1) inflection point of the curve in the graph of scree plot; and 2) eigenvalues higher than 1.0. Foods or food groups with loading factors higher than 0.25 were considered significant for the characterization of each pattern. Negative loading indicated an inverse association, and positive loads, a direct association. Cronbach's alpha verified the internal consistency of each extracted factor. The patterns were named according to the foods or/and food groups they contained.

A structured questionnaire to collect socioeconomic and demographic characteristics was administered to the heads of 366 (91\%) households with at least one child: monthly household income per member; number household dwellers (n); age (years) and parental education level (years of schooling).

The parental dietary patterns in the last year were obtained by a FFQ composed of 82 items, with the portions usually consumed and eight intake frequency options, ranging from three times a day to never/almost never. The intake of each food (portion*frequency) was scanned, with subsequent calculation of total daily intake.
The age at complementary feeding introduction was also considered an explanatory variable (in months) reported by the parents.

We followed the same aforementioned methodology to calculate the principal component analysis and to describe the paternal dietary intake, which was assessed by a FFQ. For the identification of parental dietary patterns, the 82 items listed in the FFQ were grouped into 17 food groups based on their nutritional characteristics, and correlations were obtained by preliminary factor analysis: 1) rice; 2) beans; 3) breads (bread loaf or roll); 4) starchy products (pasta, flour, biscuits, cookies, cake, popcorn, polenta or cornmeal porridge, potato, corn, cassava, and yam); 5) non-starchy vegetables (lettuce, cauliflower, chicory, cabbage, chayote, pumpkin, zucchini, string bean, gumbo, carrot, beetroot, cucumber, and tomato); 6) fruits (banana, papaya, apple, melon, pineapple, avocado, mango, lemon, passion fruit, grape, guava and pear); 7) fruit (or pulp) juice; 8) milk and dairy products (yogurt, cheese, and cottage cheese); 9) snacks (potato chips, snacks, pizza, and popcorn); 10) candies (ice cream, candies, cocoa mixes, chocolate bars, and pudding); 11) fats (bacon, mayonnaise, sausage, and butter); 12) fish and shrimp (fish, canned sardine or tuna, and shrimp); 13) meat (steak, chicken, pork, tripe, minced meat, or hamburger); 14) eggs; 15) soft drinks; 16) caffeinated beverages (coffee and mate tea); 17) sugar.

The children's birth weight (grams) and energy intake ( $\mathrm{kcal}$ ) were considered confounders after univariate analysis ( $p$-value $\leq 0.20$ ). Total energy intake was estimated from the average of two 24HR, calculated by the software Nutwin (Universidade Federal de São Paulo, São Paulo, Brazil) ${ }^{11}$. Information on foods that were not listed in the software ( $5 \%$ of the study foods) was taken from the Brazilian Table of Food Composition ${ }^{12}$, of the Universidade Estadual de Campinas, Brazil.

Initially, bivariate linear regression evaluated associations with socioeconomic and demographic variables (monthly household income per 
member; number of household dwellers; parental ages and education levels); parental dietary patterns, age at complementary feeding introduction, and children's dietary patterns. Variables with $p<0.20$ were included in the multivariate model. The models were adjusted for energy intake and child's birth weight. The significance level was set at 0.05 . All the analyses were performed by Stata 13.0 (Stata Corporation, College Station, Texas, United States) ${ }^{13}$.

\section{RES U L T S}

The households had a mean of 4.9 (Standard Deviation - SD=1.7) members, and the mean monthly household income per member was 93.9 United States dollars (USD, SD=132.3). The mean children's birth weight was 3,165 grams $(\mathrm{SD}=576.7)$, and complementary feeding was introduced at 5 months of age (SD=4.3) (Table1).

Three parental dietary patterns used as explanatory variables were identified (Table 2 ) and labeled: 1) prudent pattern, composed by vegetables, fruits, fruit juices, fish, meats, and

Table 1. Socioeconomic and demographic characteristics of the children and parents from 366 households. Duque de Caxias (RJ), Brazil, 2005.

\begin{tabular}{|c|c|c|}
\hline Variable & M & SE \\
\hline Parental & 93.9 & 132.3 \\
\hline Family income ${ }^{1}$ (USD) & 4.9 & 1.7 \\
\hline Household dwellers (n) & 33.8 & 11.1 \\
\hline \multicolumn{3}{|l|}{ Age (years) } \\
\hline \multicolumn{3}{|l|}{ Parents energy intake $(\mathrm{kcal})^{2}$} \\
\hline Children $<18$ months & 2.698 & 1.614 \\
\hline Children $>18$ months & 2.816 & 1.973 \\
\hline \multicolumn{3}{|l|}{ Children } \\
\hline Age (months) & 19.9 & 6.5 \\
\hline Birth weight (g) & 3.165 & 576.7 \\
\hline Energy intake $(\mathrm{kcal})^{3}$ & 1.018 & 428 \\
\hline Complementary feeding ${ }^{4}$ (months) & 5.0 & 4.3 \\
\hline
\end{tabular}

Note: ${ }^{1}$ Monthly household income per member (1.0 Real = 2.0 USD); ${ }^{2}$ Parental energy intake collected from the food frequency questionnaire; ${ }^{3}$ Children's energy intake calculated from the 24 -hour recall; ${ }^{4} \mathrm{Age}$ at introduction of complementary feeding.

M: Mean; SE: Standard Error
Table 2. Foods and factor loading for the dietary patterns of 366 children's parents. Duque de Caxias (RJ), Brazil, 2005.

\begin{tabular}{lccc}
\hline \multirow{2}{*}{ Food groups } & \multicolumn{3}{c}{ Dietary patterns } \\
\cline { 2 - 4 } & Health & Western & Traditional \\
\hline Rice & - & - & 0.57 \\
Beans & - & - & 0.54 \\
Breads & - & - & 0.47 \\
Grains and starchy products & - & - & 0.30 \\
Non-starchy vegetables & 0.72 & - & - \\
Fruits & 0.73 & - & - \\
Fruit juice & 0.42 & - & - \\
Milk and dairy products & - & 0.53 & - \\
Snacks & - & 0.66 & - \\
Candies & - & 0.63 & - \\
Fats & - & - & 0.46 \\
Fish and shrimp & 0.55 & - & - \\
Meats & 0.57 & - & - \\
Eggs & 0.37 & - & - \\
Soft drinks & - & 0.68 & - \\
Caffeinated beverages & - & - & 0.52 \\
Sugar & -3.6 & - & 0.52 \\
Eigenvalues & 0.64 & 0.60 & 0.50 \\
\% variance & & & 1.67 \\
Cronbach $\alpha$ & -1.1 & 10.2 \\
\hline & - & - & - \\
& & - & - \\
\hline
\end{tabular}

eggs (13.6\% intake variation); 2 ) Western pattern, characterized by milk and dairy products, snacks, candies, and sugary drinks (11.1\% variation); and 3) traditional pattern, composed of white rice, beans, bread, grains, and tubers, oil and fats, coffee and sugar (10.2\% intake variation).

Principal component analysis identified, in children aged 6 to 17 months, three dietary patterns that explained $34.7 \%$ of the total variation. The pattern named basic-mixed explained $14.5 \%$ of the intake variation and included rice, beans, bread, butter and oil, eggs, sausages and fats, and cookies and cake. The second pattern was labeled mixed-plus and explained $10.2 \%$ of the intake variation. This pattern included fruits, nonstarchy vegetables, grains and tubers, meats, cheeses and yogurt, candies, chocolate milk and sugary beverages. The third pattern, named milk and flours, explained $10.0 \%$ of the variation and was characterized by milk, baby cereals, and sugar, and negatively associated with coffee intake. 
In children older than 17 months, two dietary patterns were identified: the basic-mixed pattern (rice, beans, eggs, breads, oil and margarine, and sugary drinks) and the mixed-plus pattern (grains and tubers, fruits, non-starchy vegetables, meats, cheeses and yogurt, sausages and fats, biscuits and cakes, and candies), which explained 12.9 and $11.5 \%$ of the variation, respectively (Table 3 ).

Univariate linear regression found a positive association between age at complementary feeding introduction $(\beta=0.10 ; p<0.01)$ and basic-mixed pattern in children aged 6 to 17 months. Monthly household income per member $(\beta=0.003 ; p<0.01)$ and education level $(\beta=0.39 ; \beta=0.01)$ were positively associated with the mixed-plus pattern, and, negatively, with the traditional parental pattern' $(\beta=-0.29 ; p<0.01)$. Milk and flours pattern was positively associated with the traditional parental pattern ( $\beta=0.13 ; p=0.01)$ but negatively associated with education level $(\beta=-0.27$; $p=0.05$ ).

In children aged 18 to 30 months, age at complementary feeding introduction $(\beta=0.07$; $p=0.01)$ was associated with the basic-mixed pattern. The parental traditional dietary pattern ( $\beta=-0.09 ; p=0.03$ ) was negatively associated with the children's mixed-plus pattern (Table 4).

Multivariate linear regression for children under 18 months, adjusted for energy intake and child birth weight, found a positive association between family income $(\beta=0.002 ; p \leq 0.01)$ and the mixed-plus dietary pattern. Complementary feeding ( $\beta=0.108 ; p=0.004$ ) was positively associated with the basic-mixed dietary pattern. In children up to 18 months, parental education ( $\beta=0.368 ; p \leq 0.01)$ was positively associated with the mixed-plus dietary pattern, and age at complementary feeding introduction $(\beta=0.062$; $p=0.047$ ) was positively associated with the

Table 3. Foods and factor loading of the dietary patterns of children aged 6 to 17 months $(n=149)$ and 18 to 30 months $(n=217)$. Duque de Caxias (RJ), Brazil, 2005.

\begin{tabular}{|c|c|c|c|c|c|}
\hline \multirow{3}{*}{ Food groups } & \multicolumn{5}{|c|}{ Children's dietary patterns } \\
\hline & \multicolumn{3}{|c|}{ Age 6-17 months } & \multicolumn{2}{|c|}{ Age $18-30$ months } \\
\hline & Basic-mixed & Mixed-plus & Milk and flours & Basic-mixed & Mixed-plus \\
\hline Rice & 0.81 & - & - & 0.48 & - \\
\hline Beans & 0.26 & - & - & 0.35 & - \\
\hline Sausages and fats & 0.51 & - & - & - & 0.33 \\
\hline Eggs & 0.39 & - & - & 0.16 & - \\
\hline Bread & 0.66 & - & - & - & - \\
\hline Cookies and cake & 0.43 & - & - & - & 0.62 \\
\hline Butter and oil & 0.72 & - & - & 0.48 & - \\
\hline Grains and tubers & - & 0.32 & - & - & 0.28 \\
\hline Vegetables & - & 0.35 & - & - & 0.25 \\
\hline Fruits & - & 0.40 & - & - & 0.63 \\
\hline Meat (beef and chicken) & - & 0.53 & - & - & 0.45 \\
\hline Cheese and yogurt & - & 0.58 & - & - & 0.56 \\
\hline Sugary drinks & - & 0.60 & - & 0.32 & - \\
\hline Candy and chocolate milk & - & 0.38 & - & - & 0.34 \\
\hline Milk & - & - & 0.53 & -0.28 & - \\
\hline Baby cereals & - & - & 0.73 & -0.61 & - \\
\hline Sugar & - & - & 0.49 & -0.52 & - \\
\hline Coffee & - & - & -0.31 & 0.45 & - \\
\hline Eigenvalues & 1.01 & 1.00 & 0.99 & 1.00 & 0.99 \\
\hline$\%$ variance & 14.50 & 10.20 & 10.00 & 12.90 & 11.50 \\
\hline Cronbach $\alpha$ & 0.67 & 0.46 & 0.46 & 0.57 & 0.50 \\
\hline
\end{tabular}


basic-mixed pattern. The parental traditional dietary pattern was negatively associated with the children's mixed-plus pattern, with $\beta=-0.187$ $(p<0.01)$ for children aged 6-17 months and $\beta=-0.120(p=0.016)$ for children aged $18-30$ months (Table 5).

Table 4. Univariate linear regressions of the dietary patterns of children aged 6 to 17 months $(n=149)$ and 18 to 30 months $(n=217)$. Duque de Caxias (RJ), Brazil, 2005.

\begin{tabular}{|c|c|c|c|c|c|}
\hline \multirow{3}{*}{ Variables } & \multicolumn{5}{|c|}{$\begin{array}{c}\text { Children's dietary patterns }{ }^{\ddagger} \\
\beta \text { ( } p \text {-value })\end{array}$} \\
\hline & \multicolumn{3}{|c|}{ Age 6-17 months } & \multicolumn{2}{|c|}{ Age $18-30$ months } \\
\hline & Basic-mixed & Mixed-plus & Milk and flours & Basic-mixed & Mixed-plus \\
\hline \multirow[t]{2}{*}{ Family income (USD) ${ }^{1}$} & -0.0002 & 0.003 & -0.0002 & -0.00002 & 0.001 \\
\hline & $(0.70)$ & $(<0.01)$ & $(0.60)$ & $(0.92)$ & $(<0.01)$ \\
\hline \multirow[t]{2}{*}{ Household dwellers ( $n$ ) } & -0.04 & -0.09 & 0.02 & 0.09 & -0.06 \\
\hline & $(0.32)$ & $(0.01)$ & $(0.47)$ & $(0.02)$ & $(0.07)$ \\
\hline \multirow[t]{2}{*}{ Age (years) ${ }^{2}$} & -0.01 & -0.003 & -0.001 & -0.002 & -0.003 \\
\hline & $(0.06)$ & $(0.62)$ & $(0.86)$ & $(0.66)$ & $(0.48)$ \\
\hline \multirow[t]{2}{*}{ Education level (years) } & 0.33 & 0.39 & -0.27 & -0.12 & 0.40 \\
\hline & $(0.05)$ & $(0.01)$ & $(0.05)$ & $(0.35)$ & $(<0.01)$ \\
\hline \multirow[t]{2}{*}{ Prudent pattern ${ }^{3}$} & 0.10 & 0.04 & 0.05 & 0.09 & 0.03 \\
\hline & $(0.05)$ & $(0.36)$ & $(0.19)$ & $(0.01)$ & $(0.24)$ \\
\hline \multirow[t]{2}{*}{ Western pattern ${ }^{3}$} & 0.40 & 0.03 & -0.006 & 0.03 & 0.006 \\
\hline & $(0.48)$ & $(0.61)$ & $(0.21)$ & $(0.33)$ & $(0.84)$ \\
\hline \multirow[t]{2}{*}{ Traditional pattern ${ }^{3}$} & 0.03 & -0.29 & 0.13 & 0.08 & -0.09 \\
\hline & $(0.57)$ & $(<0.01)$ & $(0.01)$ & $(0.12)$ & $(0.03)$ \\
\hline \multirow[t]{2}{*}{ Complementary feeding } & 0.10 & 0.001 & -0.01 & 0.07 & -0.02 \\
\hline & $(<0.01)$ & $(0.46)$ & $(0.54)$ & $(0.01)$ & $(0.91)$ \\
\hline
\end{tabular}

Note: ${ }^{1}$ Monthly household income per member (1.0 Real $=2.0$ USD); ${ }^{2}$ Age at introduction of complementary feeding; ${ }^{3}$ Dietary patterns of the 366 children's parents; ${ }^{*}$ Univariat e linear regressions.

Table 5. Multivariate linear regressions of the dietary patterns of children aged 6 to 17 months $(n=149)$ and 18 to 30 months ( $n=217)$. Duque de Caxias (RJ), Brazil, 2005.

\begin{tabular}{|c|c|c|c|c|c|}
\hline \multirow{3}{*}{ Variables } & \multicolumn{5}{|c|}{$\begin{array}{c}\text { Children's dietary patterns* } \\
\qquad \beta \text { ( } p \text {-value) }\end{array}$} \\
\hline & \multicolumn{3}{|c|}{ Age 6-17 months } & \multicolumn{2}{|c|}{ Age $18-30$ months } \\
\hline & Basic-mixed & Mixed-plus & Milk and flours & Basic-mixed & Mixed-plus \\
\hline \multirow[t]{2}{*}{ Family income ${ }^{1}$} & - & 0.002 & - & - & 0.001 \\
\hline & & $(<0.01)$ & & & $(0.007)$ \\
\hline \multirow[t]{2}{*}{ Parental age (years) } & -0.015 & - & - & - & \\
\hline & $(0.049)$ & & & & \\
\hline \multirow[t]{2}{*}{ Parental education level (years) } & - & - & - & - & 0.368 \\
\hline & & & & & $(<0.01)$ \\
\hline \multirow[t]{2}{*}{ Prudent pattern ${ }^{2}$} & - & - & - & 0.089 & - \\
\hline & & & & $(0.024)$ & \\
\hline \multirow[t]{2}{*}{ Traditional pattern² } & - & -0.187 & 0.152 & - & -0.120 \\
\hline & & $(<0.01)$ & $(0.006)$ & & $(0.016)$ \\
\hline \multirow[t]{2}{*}{ Complementary feeding ${ }^{3}$} & 0.108 & - & - & 0.062 & - \\
\hline & (0.004) & & & $(0.047)$ & \\
\hline
\end{tabular}

Note: *Multivariate linear model: adjusted for energy intake and birth weight. ${ }^{1}$ Monthly household income per member (1.0 Real = 2.0 USD); ${ }^{2}$ Dietary pattern of 366 children's parents; ${ }^{3} \mathrm{Age}$ at introduction of complementary feeding. 


\section{DISCUSSION}

The study found three different dietary patterns in children less than 18 months of age and an association with the following explanatory variables: family income, parental dietary intake, and complementary feeding. The milk and flours dietary pattern identified in children less than 18 months of age regarded a monotonous diet. On the other hand, children aged 18-30 months presented only two dietary patterns, including the consumption of some food groups that suggested a greater participation in the family's diet, such as the intake of coffee and a possible substitution of milk and baby cereals for sugary drinks.

It is important to highlight that two mixed patterns were found in both groups of children. The first was named basic-mixed and consisted of basic foods, such as rice and beans, and also of processed foods, such as cookies, cakes, butter, and oils. The other dietary pattern, named mixedplus, was characterized by fruits, vegetables, and yogurt, but it also included unhealthy foods (candies, sugary drinks, sausages, and salty products). This pattern was similar to the one found in Brazilian adults by Marchioni et al. ${ }^{4}$ and Bezerra \& Sichieri ${ }^{14}$, which revealed that the intake of healthy foods does not necessarily exclude the intake of energy-dense or nutrient-sparse foods.

Children under 30 months of age are already susceptible to the early introduction of processed foods and high intake of bread, biscuits, cakes, commercially processed products, and sausages, similar to the diet of adult Brazilians ${ }^{15}$. These results are corroborated by Toloni et al. ${ }^{16}$, who found early introduction of candies, instant noodles, sausages, soft drinks, and drink mixes in children aged four to twenty nine months from public daycare centers in São Paulo/Brazil.

Kudlová \& Schneidrová ${ }^{17}$ examined the feeding patterns of 1-5-year-olds from Prague and verified that the intake frequency of milk and dairy products, fruits, vegetables, and poultry decreased significantly with age, and that the intake frequency of smoked meat and meat products, sweets, and deep-fried foods increased significantly with age. Also, a study from the United States reported that $46 \%$ of the children aged seven to eight months had already consumed some type of candy or sugary drink ${ }^{18}$. Similarly, Rangan et al. ${ }^{19}$ found that $24 \%$ of the total daily intake of Australian two- and three-year-olds consisted of energy-dense foods, such as soft drinks, fatty and sweet cookies, and potato chips.

The reduction of milk intake and inclusion of sugary drinks (soft drinks and drink mixes) as children age is another aspect to consider. A diet high in sugar and fat is associated with childhood overweight and obesity ${ }^{20}$, as well as diets low in fruits and non-starchy vegetables 21,22 .

Socioeconomic and demographic factors also determined the dietary patterns of the study sample. Monthly household income per member was associated with the mixed-plus dietary pattern in both groups of children. Children from families with higher income had a more varied diet. This result is corroborated by D'Innocenzo et al. ${ }^{23}$, who studied children aged 4 to 11 years from Salvador/Brazil and found that having better socioeconomic level resulted in greater dietary diversity with the presence of health foods, like fruits, green vegetables, legumes, grains, fish, milk, and dairy products, among others. The Family Budget Survery ${ }^{24}$ also reported a similar trend: the intake of dairy products, fruits, nonstarchy vegetables, animal fat, and soft drinks increased with family income.

The positive association between parental education level and the intake of fruits and vegetables in children aged 18 to 30 months in the mixed-plus pattern is confirmed by the literature ${ }^{25,26}$. On the other hand, as this pattern was also characterized by foods not indicated for the study age group, having higher education level did not necessarily lead to healthy food intake per se. Parents with a higher education level tend to have higher purchasing power, giving their children access to a more varied diet, which may, therefore, justify this finding. 
When analyzing the influence of parental dietary patterns on the children's dietary patterns, the study found, in both age groups, that children whose parents had higher access to the traditional pattern, composed of basic and low-price foods, such as rice, beans, bread, grains, coffee, and sugar, had a lower intake of the mixed-plus pattern. This demonstrates that these children, who were starting complementary feeding, a phase that should include a diverse diet, and which is important for the formation of food habits, had inadequate intake of nutrient-dense foods. The traditional parental pattern was also associated with the children's pattern milk and flours, corroborating the hypothesis that these families prioritize milk for children less than 18 months of age.

Other studies have already reported the correlation between the diets of parents and children less than 3 years. For example, Fisk et al. ${ }^{7}$ found that children of mothers who had a diet high in fruits, vegetables, and wholemeal bread were likely to have a comparable diet at age 3 years. Conversely, children of mothers whose diets were characterized mostly by white bread, crisps, and confectionery were more likely to have lowquality diets. Lioret et al. ${ }^{27}$ also found that higher maternal adherence to the pattern labelled fruits and vegetables predicted higher scores for their children in the pattern positively correlated with healthy food intake (vegetables, fish, fruits, animal products, pasta and rice, and milk) and inversely correlated with sweet intake.

Finally, evaluation of the influence of age at complementary feeding introduction on the children's dietary patterns showed that later introduction resulted in higher scores for the pattern basic-mixed in both age groups. This pattern is probably explained by the replacement of breastfeeding by the parents' diet.

It is important to consider the study limitations. A cross-sectional design does not allow the establishment of a causal inference. Another limitation would be the use of the $24 \mathrm{HR}$ to identify the children's intake patterns. However, this method was chosen because it is widely used in this age group ${ }^{28}$. Additionally, the use of factor analysis implies some subjectivity in the selection of the number of extracted factors.

Therefore, this study has shown that parental dietary patterns, age at complementary feeding introduction, and sociodemographic factors, such as family income and schooling, were associated with the children's dietary patterns. These findings should be taken into account by primary healthcare nutritional surveillance.

\section{CONCLUSION}

In conclusion, some household socioeconomic and demographic characteristics were associated with the children's dietary patterns. Two mixed patterns were found, one composed of basic foods and the other, of fruits and vegetables. Early introduction of complementary feeding was positively associated with the milk and flour dietary pattern. On the other hand, the parental traditional pattern was negatively associated with the children's mixed-plus dietary pattern in both age groups. These factors should be considered in order to support actions that promote healthy diets, targeting both children and parents.

\section{CONTRIBUTORS}

R SALLES-COSTA conceptualized the study, coordinated the research and financial support, and contributed to the writing and review of the manuscript. GS BARROSO participated in data collection, data analysis, and manuscript development and writing. $M$ CABRAL collaborated to the written discussion and reviewed the manuscript. MBT CASTRO collaborated to data analysis, and writing and review of the manuscript.

\section{REFERE NCES}

1. Nicklaus S, Boggio V, Chabanet C, Issanchou S. A prospective study of food variety seeking in 
childhood, adolescence and early adult life. Appetite. 2005; 44(3):289-97. http://dx.doi.org/10. 1016/j.appet.2008.09.018

2. American Dietetic Association. Position of the American Dietetic Association: Nutrition guidance for health children ages 2 to 11 years. J Am Diet Assoc. 2004; 104(4):660-77.

3. Fung C, Mclsaac JL, Kuhle S, Kirk SF, Veugelers PJ. The impact of a population-level school food and nutrition policy on dietary intake and body weights of Canadian children. Prev Med. 2013; 57(6):934-40. http://dx.doi.org/10.1016/j.ypmed.2013.07.016

4. Marchioni DM, Claro RM, Renata B, Levy RB, Monteiro CA. Patterns of food acquisition in Brazilian households and associated factors: A populationbased survey. Public Health Nutr. 2011; 14(9):1586-92. http://dx.doi.org/10.1017/S1368980011001157

5. Olinto MTA. Padrões alimentares: anáilise de components principais. In: Epidemiologia nutricional. Rio de Janeiro: Fiocruz; 2007.

6. Robinson S, Marriott L, Poole J, Crozier S, Borland S, Lawrence $W$, et al. Dietary patterns in infancy: The importance of maternal and family influences on feeding practice. Br J Nutr. 2007; 98(5):1029-37. http://dx.doi.org/10.1111/j.1469-7610.2008.02 029.x

7. Fisk CM, Crozier SR, Inskip HM, Godfrey KM, Cooper C, Robinson SM. Influences on the quality of young children's diets: The importance of maternal food choices. Br J Nutr. 2011; 105(2):287-96. http:// dx.doi.org/10.3390/nu4080859

8. Smithers LG, Brazionis L, Golley RK, Mittinty MN, Northstone K, Emmett $\mathrm{P}$, et al. Associations between dietary patterns at 6 and 15 months of age and socioeconomic and demographic factors. Eur J Clin Nutr. 2012; 66(6):658-66. http://dx. doi.org/10.1038/ejcn.2011.219

9. Barroso GS, Sichieri R, Salles-Costa R. Relationship of socio-economic factors and parental eating habits with children's food intake in a populationbased studying a metropolitan area of Brazil. Public Health Nutr. 2014; 17(1):156-61. http://dx.doi.org/ 10.1017/S1368980012004624

10. Sichieri R, Everhart J. Validity of a Brazilian food frequency questionnaire against dietary recalls and estimated energy intake. Nutr Res. 1998; 18(10): 1649-59. http://dx.doi.org/10.1016/S0271-53 17(98)00151-1

11. Universidade Federal de São Paulo. Programa de Apoio a Nutrição: NutWin. São Paulo: Universidade Federal de São Paulo; 2005.

12. Núcleo de Estudos e Pesquisas em Alimentação. Tabela de Composição de Alimentos - TACO. Campinas: Unicamp; 2004.
13. Stata for Windows, version 13. College Station (TX): Stata Corporation; 2013.

14. Bezerra IN, Sichieri R. Household food diversity and nutritional status among adults in Brazil. Int J Behav Nutr Phys Act. 2011; 8:22. http://dx.doi.org/ 10.1186/1479-5868-8-22

15. Instituto Brasileiro de Geografia e Estatística. Pesquisa de orçamentos familiares - POF 2008/ 2009: análise do consumo alimentar pessoal no Brasil. Rio de Janeiro: IBGE; 2010.

16. Toloni MHA, Longo-Silva G, Goulart RMM, Carrazedo TJAA. Introdução de alimentos industrializados e de alimentos de uso tradicional na dieta de crianças de creches públicas no Município de São Paulo. Rev Nutr. 2011; 24(1):61-70. http://dx.doi. org/10.1590/S1415-52732011000100006

17. Kudlová E, Schneidrová D. Dietary patterns and their changes in early childhood. Cent Eur J Public Health. 2012; 20(2):126-34.

18. Fox MK, Pac S, Devaney B, Jankowski L. Feeding infants and toddlers study: What foods are infants and toddlers eating? J Am Diet Assoc. 2004; 104(Suppl. 1):S22-S30. http://dx.doi.org/10.1016/ j.jada.2003.10.026

19. Rangan AM, Kwan J, Flood VM, Louie JCY, Gill, TP. Changes in 'extra' food intake among Australian children between 1995 and 2007. Obes Res Clin Pract. 2011; 5(1):e55-e63. http://dx.doi.org/10.10 16/j.orcp.2010.12.001

20. Dubois L, Farmer A, Girard M, Peterson K. Regular sugar-sweetened beverage consumption between meals increases risk of overweight among preschool-aged children. J Am Diet Assoc. 2007; 107(6):924-34. http://dx.doi.org/10.3305/nh.20 13.28.1.6247

21. Overby NC, Lillegaard ITL, Johansson L, Andersen LF. High intake of added sugar among Norwegian children and adolescents. Public Health Nutr. 2003; $7(2): 285-93$.

22. Kranz S, Smiciklas-Wright $H$, Siega-Riz AM, Mitchell D. Adverse effect of high added sugar consumption on dietary intake in American preschoolers. J Pediatr. 2005; 146(1):105-11. http://dx.doi.org/10. 1016/j.jpeds.2004.08.077

23. D'Innocenzo S, Marchioni DML, Prado MS, Matos SMA, Pereira SRS, Barros AP, et al. Condições socioeconômicas e patterns alimentares de crianças de 4 a 11 anos: estudo SCAALA - Salvador/Bahia. Rev Bras Saúde Matern Infant. 2011; 11(1):41-9. http://dx.doi.org/10.1590/S1519-38292011 000100005

24. Instituto Brasileiro de Geografia e Estatística. Pesquisa de Orçamentos Familiares - POF 2008/2009: 
avaliação nutricional da disponibilidade domiciliar de alimentos no Brasil. Rio de Janeiro: IBGE; 2010.

25. Vereecken CA, Keukekier E, Maes L. Influence of mother's education level on food parenting practices and food habits of young children. Appetite. 2004; 43(1):93-103.

26. Moreira P, Santos S, Padrão P, Cordeiro T, Bessa M, Valente $\mathrm{H}$, et al. Food patterns according to socioeconomic and demographics, physical activity, sleeping and obesity in Portuguese children. Int J Environ Res Public Health. 2010; 7(3):1121-38. http://dx.doi.org/10.3390/ijerph7031121

27. Lioret S, Cameron AJ, McNaughton SA, Crawford D, Spence AC, Hesketh K, et al. Association between maternal education and diet of children at 9 months is partially explained by mothers' diet. Matern Child Nutr. 2015; 11(4):936-47. http://dx.doi.org/10.11 11/mcn. 12031

28. Livingstone MBE, Robson PJ, Wallace JM. Issues in dietary intake assessment of children and adolescentes. Br J Nutr. 2004; 92(Suppl. 2):S213-22. http://dx.doi.org/10.1079/BJN20041169

Received: April 9, 2015

Final version: February 11, 2016

Approved: February 25, 2016 
